\title{
KAJIAN PENGURANGAN RISIKO BENCANA BANJIR DI DAS CILIWUNG
}

\author{
Priyanka Prajna Paramitha ${ }^{1}$, Dr. Rudy P Tambunan, M.S ${ }^{2}$, \\ Dr. Tito Latif Indra, S.Si, M.Si ${ }^{2}$, \\ ${ }^{1}$ Sekolah Ilmu Lingkungan, Pascasarjana Universitas Indonesia \\ ${ }^{2}$ Departemen Geografi, FMIPA Universitas Indonesia \\ Email: priyankaririn@gmail.com
}

\begin{abstract}
ABSTRAK
Laju pertumbuhan penduduk dan kepadatan penduduk yang tinggi menyebabkan kompleksitas permasalahan lingkungan, salah satunya adalah permasalahan banjir. Laju pertumbuhan penduduk yang tinggi mendesak ruang-ruang terbuka hijau dan sempadan sungai berubah menjadi wilayahwilayah yang padat dengan permukiman seperti yang terjadi di Daerah Aliran Sungai (DAS) Ciliwung. Ancaman bencana banjir, kondisi sosial dan ekonomi serta pembangunan infrastruktur dari hulu sampai dengan hilir DAS Ciliwung semakin meningkatkan risiko bencana banjir di DAS Ciliwung. Tujuan penelitian ini adalah menganalisis ancaman bencana banjir, kerentanan (sosial dan ekonomi), kapasitas daerah dan masyarakat di DAS Ciliwung, menganalisis risiko bencana banjir di DAS Ciliwung, menganalisis alternatif pengurangan risiko bencana banjir di DAS Ciliwung. Metode yang digunakan dalam riset ini adalah metode kuantitatif dan kualitatif dengan menggunakan data sekunder, data primer melalui pengisian kuesioner oleh pemangku kepentingan/Instansi dan penduduk yang terdampak banjir di DAS Ciliwung. Analisis yang digunakan adalah analisis deskriptif-kuantitatif dan analisis AHP untuk menentukan pemilihan alternatif pengurangan risiko bencana banjir. Hasil penelitian menunjukan bahwa tingkat ancaman bencana banjir di DAS Ciliwung baik di segmen tengah maupun di segmen hilir berada dikategori tinggi. Selain ancaman bencana banjir, tingkat kerentanan sosial ekonomi di DAS Ciliwung juga termasuk dalam kategori tinggi. Sedangkan dari sisi kapasitas masyarakat dan daerah, kapasitas masyarakat dan daerah pada segmen hilir lebih siap dibandingkan dengan masyarakat yang berada di segmen tengah. Tetapi walaupun kapasitas pada segmen hilir lebih siap, tidak dapat mengurangi risiko bencana banjir yang tinggi. Permasalahan tingginya risiko bencana banjir diatasi melalui alternatif pengurangan risiko bencana. Berdasarkan hasil AHP, maka diperoleh prioritas alternatif dengan bobot tertinggi yaitu peningkatan efektivitas pencegahan dan mitigasi bencana.
\end{abstract}

Kata Kunci : Risiko Bencana Banjir, Daerah Aliran Sungai Ciliwung, Pengurangan Risiko Bencana Banjir, Kapasitas Daerah 


\section{PENDAHULUAN}

Laju pertumbuhan penduduk dan kepadatan penduduk yang tinggi menyebabkan kompleksitas permasalahan lingkungan, salah satunya adalah permasalahan banjir. Laju pertumbuhan penduduk yang tinggi mendesak ruang-ruang terbuka hijau dan sempadan sungai berubah menjadi wilayah-wilayah yang padat dengan permukiman. Akibatnya, daerah resapan air dan wilayah sempadan sungai yang semula sebagai bagian run off air hujan pun menjadi tidak optimal. Curah hujan yang tinggi berafiliasi dengan minimnya ruang terbuka hijau dan tidak optimalnya fungsi sungai menyebabkan terjadinya banjir. Seperti perubahan penggunaan lahan di kawasan Jakarta, Bogor dan Depok yang telah memberi dampak terhadap frekuensi, debit dan volume banjir di DAS Ciliwung yang mengakibatkan kerusakan dan kerugian material maupun non material terutama di bagian hilir Sungai Ciliwung.

Pada Tanggal 05 Februari 2018 terjadi curah hujan ringan hingga ekstrim di wilayah Jabodetabek dengan konsentrasi hujan tertinggi di Bogor 169 mm/hari kategori ekstrim (BMKG,2018) seperti yang digambarkan pada Gambar 1. Hal tersebut menyebabkan Bendung Katulampa mengalami kenaikan status siaga mencapai $130 \mathrm{~cm}$ Siaga III (waspada) pada pukul 07:00 WIB dan mengalami kenaikan hingga pukul 08.30 WIB, tinggi muka air di Bendung Katulampa mencapai $240 \mathrm{~cm}$ siaga I (bencana) selama 4 jam. Imbas akibat Katulampa Siaga I, beberapa kelurahan di Daerah Aliran Sungai (DAS) Ciliwung terdampak bencana banjir. Berdasarkan data dari BBWSCC, BPBD DKI Jakarta dan BPBD Kota Bogor pada tahun 2018, terdapat empat kelurahan di Provinsi DKI Jakarta dan di Kota Bogor yang paling parah terdampak banjir, yang terdiri dari dua kelurahan di Provinsi DKI Jakarta yaitu Kelurahan Balekambang, dan Kelurahan Srengseng Sawah dengan ketinggian banjir mencapai $300 \mathrm{~cm}$ serta dua kelurahan di Kota Bogor yaitu Kelurahan Tanah Sareal dan Kelurahan Kedunghalang dengan ketinggian banjir mencapai $150 \mathrm{~cm}$.

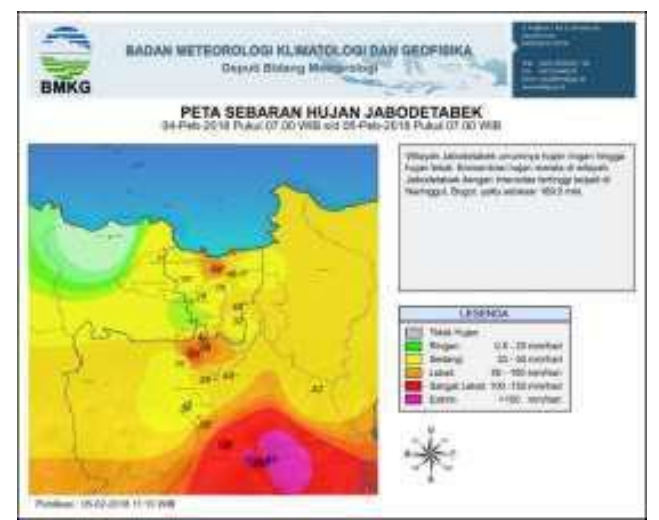

Gambar 1. Peta Sebaran Hujan Jabodetabek Sumber : BMKG, 2018 
Mengingat bencana banjir, terutama di wilayah perkotaan dapat menyebabkan kerugian yang besar, maka pemetaan risiko bencana banjir sangat diperlukan. Risiko bencana sangat dipengaruhi oleh kerentanan dan kapasitas dalam menghadapi ancaman yang ada (Perka BNPB No. 2 Tahun 2012 tentang Pedoman Umum Pengkajian Risiko Bencana). Curah hujan tinggi dalam waktu yang pendek, daya dukung lingkungan yang semakin menurun, kondisi sosial dan ekonomi serta pembangunan infrastruktur, dari hulu sampai dengan hilir DAS Ciliwung semakin meningkatkan ancaman bencana dan kerentanan banjir di DAS Ciliwung.

Berdasarkan latar belakang yang telah dijelaskan, terdapat risiko bencana banjir akibat adanya ancaman bencana banjir akibat luapan sungai Ciliwung dan kondisi sosial ekonomi masyarakat yang rentan terhadap bencana banjir, hal ini seharusnya dapat dikurangi dengan meningkatkan kapasitas masyarakat maupun daerah dalam pengurangan risiko bencana banjir dari segmen tengah DAS Ciliwung sampai dengan hilir. Oleh karena itu diperlukan kajian pengurangan risiko bencana banjir di DAS Ciliwung.

\section{METODOLOGI}

Penelitian ini menggunakan pendekatan kuantitatif. Metode yang digunakan adalah gabungan antara kualitatif dan kuantitatif. Penggunaan metode kuantitatif pada penelitian ini yaitu menggunakan Sistem Informasi Geografi (SIG). Metode kualitatif pada penelitian ini adalah pengumpulan data melalui pengisian kuesioner oleh pemangku kepentingan/Instansi dan penduduk yang terdampak banjir di DAS Ciliwung.

Penelitian ini dilaksanakan pada bulan Januari tahun 2019 - Mei tahun 2019. Tempat penelitian berada di segmen tengah sampai dengan hilir Das Ciliwung. Pemilihan tempat penelitian ditentukan secara purposive (secara sengaja) dengan pertimbangan data dari BBWSCC, BPBD DKI Jakarta dan BPBD Kota Bogor pada tahun 2018, terdapat empat kelurahan di Provinsi DKI Jakarta dan di Kota Bogor yang paling parah terdampak banjir, yang terdiri dari dua kelurahan di Provinsi DKI Jakarta yaitu Kelurahan Balekambang, dan Kelurahan Srengseng Sawah serta dua kelurahan di Kota Bogor yaitu Kelurahan Tanah Sareal dan Kelurahan Kedunghalang. Penelitian dimulai dengan pengumpulan data primer maupun data sekunder, kemudian data diolah dan dianalisis hingga penyusunan laporan penelitian. 


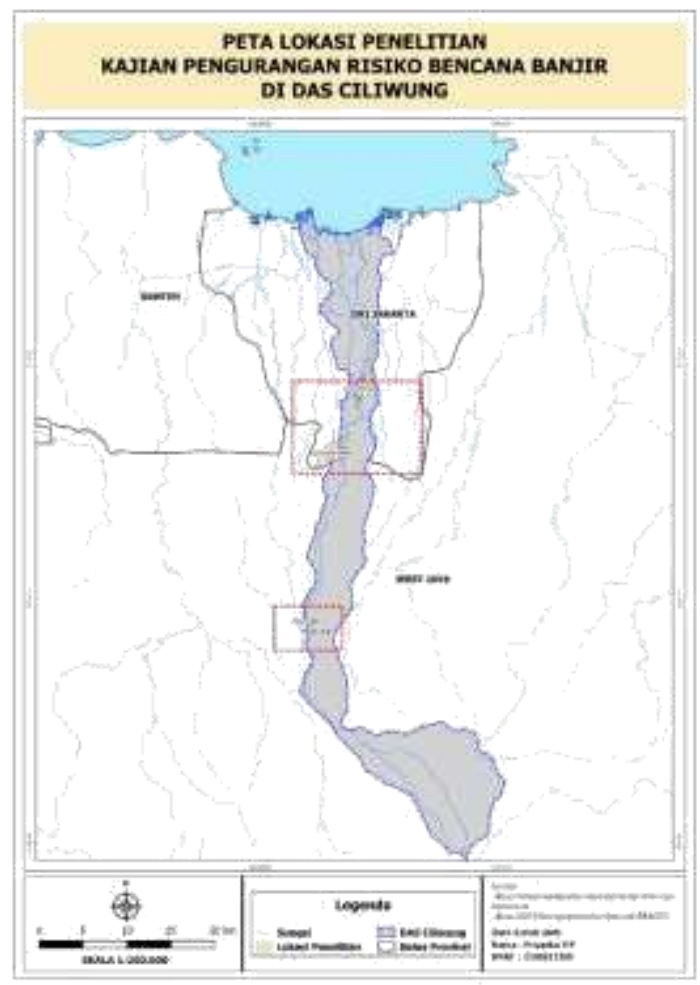

Gambar 2. Peta Lokasi Penelitian Sumber : Hasil olahan, 2019

Populasi pada penelitian ini terbagi menjadi dua, yaitu penduduk disekitar wilayah penelitian dan pemangku kepentingan. Populasi pertama adalah semua Kepala Keluarga (KK) yang bertempat tinggal di lokasi studi yaitu kelurahan Balekambang, Kelurahan Srengseng Sawah, Kelurahan Tanah Sareal dan Kelurahan Kedunghalang. Jumlah populasi yaitu 35592 KK. Jumlah sampel dalam penelitian ini ditentukan menggunakan rumus slovin (lihat rumus 3.1) dengan derajat kesalahan $10 \%$ :

$$
\mathrm{n}=\mathrm{N} /\left(1+\left(\mathrm{Nx} \mathrm{e}^{2}\right)\right.
$$

\section{Keterangan:}

$$
\begin{array}{ll}
\mathrm{n} & =\text { jumlah sampel } \\
\mathrm{N} & =\text { jumlah target populasi } \\
\mathrm{e} & =\text { jumlah toleransi kesalahan }
\end{array}
$$

Perkiraan jumlah sampel penelitian (n) selanjutnya dihitung sebagai berikut:

$$
\mathrm{n}=35592 /\left(1+\left(35592 \times 0.1^{2}\right)=99.7\right.
$$


Berdasarkan hasil perhitungan tersebut maka didapatkan jumlah sampel sebanyak 100 responden. Sampel tersebut kemudian menjadi responden dan diperoleh menggunakan metode purposive sampling. Adapun kriteria responden adalah sebagai berikut:

a. Kepala Keluarga (KK) yang terdampak banjir

b. Bersedia menjadi sumber data

Populasi kedua adalah pemangku kepentingan (stakeholder) yaitu aparatur pemerintah yang terlibat dalam pembuatan kebijakan atau program yang terkait dengan pengurangan risiko bencana banjir di DAS Ciliwung. Penentuan sampel dilakukan dengan teknik purposive sampling yaitu dengan menentukan key person yang dapat memberikan informasi terkait kebijakan atau program pengurangan risiko bencana di DAS Ciliwung. Metode pengumpulan data menggunakan metode pengisian kuesioner dan wawancara. Jumlah Sampel pemangku kepentingan sebanyak 3 responden dengan kriteria sebagai berikut:

a. Terlibat dalam pembuatan kebijakan atau program pengurangan risiko bencana banjir

b. Masa jabatan di instansi tersebut minimal 2 tahun.

Berdasarkan kriteria tersebut, maka peneliti memilih instansi sebagai berikut:

Tabel 1. Instansi Pemangku Kepentingan

\begin{tabular}{|c|l|l|l|}
\hline No. & \multicolumn{1}{|c|}{ Instansi } & \multicolumn{1}{|c|}{ Informasi yang dibutuhkan } & \multicolumn{1}{|c|}{$\begin{array}{l}\text { Jumlah } \\
\text { Sampel }\end{array}$} \\
\hline 1 & $\begin{array}{l}\text { Badan Penanggulangan Bencana } \\
\text { Daerah Provinsi DKI Jakarta }\end{array}$ & $\begin{array}{l}\text { Program pengurangan risiko bencana di } \\
\text { DKI Jakarta }\end{array}$ & 1 orang \\
\hline 2 & $\begin{array}{l}\text { Badan Penanggulangan Bencana } \\
\text { Daerah Provinsi Jawa Barat }\end{array}$ & $\begin{array}{l}\text { Program pengurangan risiko bencana di } \\
\text { Jawa Barat }\end{array}$ & 1 orang \\
\hline 3 & $\begin{array}{l}\text { Badan Penanggulangan Bencana } \\
\text { Daerah Kota Bogor }\end{array}$ & $\begin{array}{l}\text { Program pengurangan risiko bencana di } \\
\text { Kota Bogor }\end{array}$ & 1 orang \\
\hline
\end{tabular}

Analisis penelitian berdasarkan tujuan penelitian terdapat empat analisis yaitu analisis tingkat ancaman, kerentanan dan risiko bencana banjir di DAS Ciliwung, analisis kesiapsiagaan masyarakat dalam pengurangan risiko bencana banjir di DAS Ciliwung, analisis kapasitas daerah dalam pengurangan risiko bencana banjir di DAS Ciliwung dan analisis alternatif pengurangan risiko bencana banjir.

Analisis tingkat ancaman, kerentanan dan risiko bencana banjir di DAS Ciliwung diperoleh melalui studi literatur. Data diolah dengan menggunakan perhitungan statistik sederhana dalam bentuk tabel, diagram atau grafik dan diolah dengan metode sistem 
informasi geografis dan ditampilkan dalam bentuk peta. Analisis ini dilakukan untuk mengetahui tingkat ancaman, kerentanan dan risiko bencana banjir di DAS Ciliwung.

Analisis kesiapsiagaan masyarakat dalam pengurangan risiko bencana banjir di DAS Ciliwung terdiri dari lima variabel yaitu variabel pengetahuan, sikap, rencana tanggap darurat, sistem peringatan bencana dan mobilisasi sumber daya. Untuk mengolah data yang terkumpul dalam penelitian ini mengunakan analisis nilai indeks dengan menggunakan teknik perhitungan indeks skor. Data yang terkumpul berwujud angka hasil tabulasi, kemudian dijelaskan menurut urutan informasi yang ingin diketahui. Data disajikan dalam bentuk tabel dan grafik, kemudian ditafsirkan dalam kalimat deskriptif. Analisis indeks dalam penelitian ini digunakan untuk mengetahui tingkat kesiapsiagaan masyarakat. Indeks merupakan angka perbandingan antara satu bilangan dengan bilangan lain yang berisi informasi tentang suatu karakteristik tertentu pada waktu dan tempat yang sama atau berlainan. Angka indeks dalam penelitian ini meliputi indeks per variabel. Semakin tinggi angka indeks berarti semakin tinggi pula tingkat kesiapsiagaan dari subjek yang diteliti. Tingkat kesiapsiagaan dalam penelitian ini dikategorikan menjadi lima, rentang kategori dapat dilihat pada tabel 2.

Tabel 2. Tingkat Kesiapsiagaan Bencana

\begin{tabular}{|c|c|c|}
\hline No & Nilai Indeks & Kategori \\
\hline $\mathbf{1}$ & $80-100$ & Sangat Siap \\
\hline $\mathbf{2}$ & $65-79$ & Siap \\
\hline $\mathbf{3}$ & $55-64$ & Hampir Siap \\
\hline $\mathbf{4}$ & $40-54$ & Kurang Siap \\
\hline $\mathbf{5}$ & Kurang dari $40(0-39)$ & Belum Siap \\
\hline
\end{tabular}

Sumber : LIPI-UNESCO/ISDR, 2006

Analisis kapasitas daerah dalam pengurangan risiko bencana banjir di DAS Ciliwung berdasarkan variabel kebijakan. Intrumen yang digunakan adalah kuesioner. Kuesioner ini disusun untuk mendapatkan sebuah tingkatt kapasitas daerah.

Analisis alternatif pengurangan risiko bencana banjir dikaji menggunakan metode AHP agar dapat diketahui alternatif mana yang menjadi prioritas untuk pengurangan risiko bencana, apakah pengkajian risiko dan perencanaan terpadu, penanganan tematik kawasan rawan bencana atau peningkatan efektivitas pencegahan dan mitigasi bencana. Penggunaan 
metode AHP diawali dengan penyusunan struktur hirarki. Berdasarkan hirarki yang telah disusun, selanjutnya dilakukan wawancara dan pemberian kuesioner kepada para pemangku kepentingan. Setiap parameter input memiliki intensitas kepentingan yang tidak sama antara satu dengan yang lain dalam mempengaruhi suatu model. Perbandingan berpasangan AHP menjadi salah satu cara untuk mengetahui tingkat kepentingan masing-masing parameter.

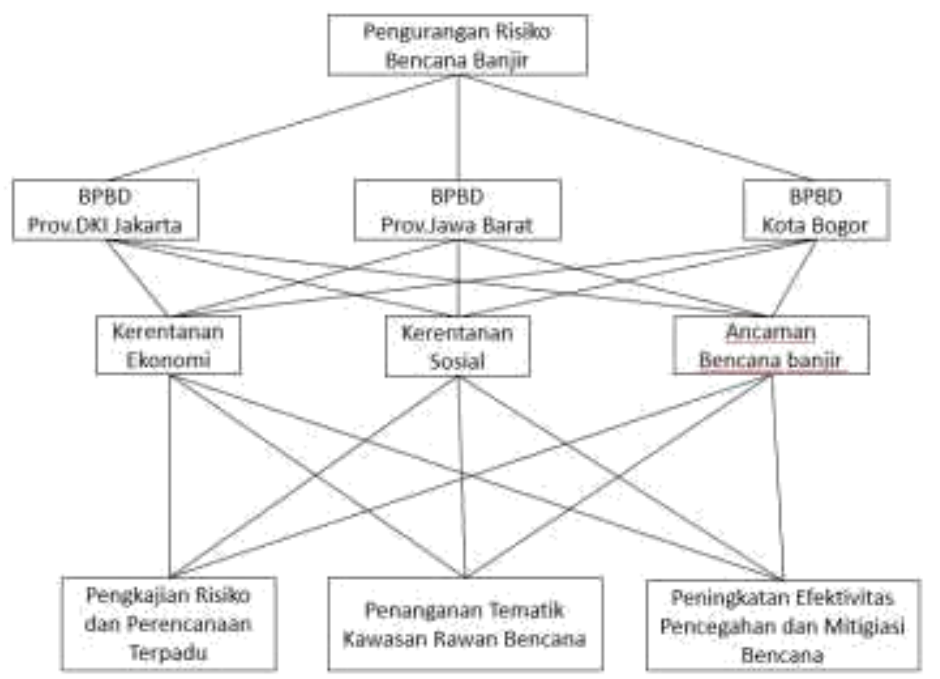

Gambar 3. Struktur Hirarki Pengurangan Risiko Bencana Banjir di DAS Ciliwung

Intensitas kepentingan dalam penelitian ini diperoleh dari sampel pemangku kepentingan melalui diskusi wawancara dan kuisioner. Intensitas kepentingan tersebut adalah bahan untuk menghasilkan bobot setiap parameter. Setiap parameter dilakukan perbandingan berpasangan dengan jumlah perbandingan yang mengikuti rumus (3.2) dengan $n$ sebagai jumlah parameter yang dibandingkan.

$$
\frac{1}{2} n(n-1)
$$

Bahwa : $n=$ Jumlah parameter dalam grup perbandingan pairwise 


\section{HASIL DAN PEMBAHASAN}

\section{1) Ancaman Bencana Banjir}

Berdasarkan Gambar 4. Kelurahan Kedaunghalang terdiri dari tiga kelas bahaya banjir yaitu rendah, sedang dan tinggi. kelas bahaya rendah 2,5 ha atau $1,3 \%$ wilayah Kelurahan Kedunghalang, kelas bahaya sedang yaitu seluas 2,2 ha atau 1,2\% wilayah Kelurahan Kedunghalang dan seluas 12,9 ha atau 6,9\% wilayah Kelurahan Kedunghalang untuk kelas bahaya tinggi. Pada Gambar 5. menggambarkan bagaimana kondisi banjir Kelurahan Kedunghalang tepatnya di Kampung Rawa Bebek pada tanggal 05 Februari 2018 dengan ketinggian banjir $70 \mathrm{~cm}$.

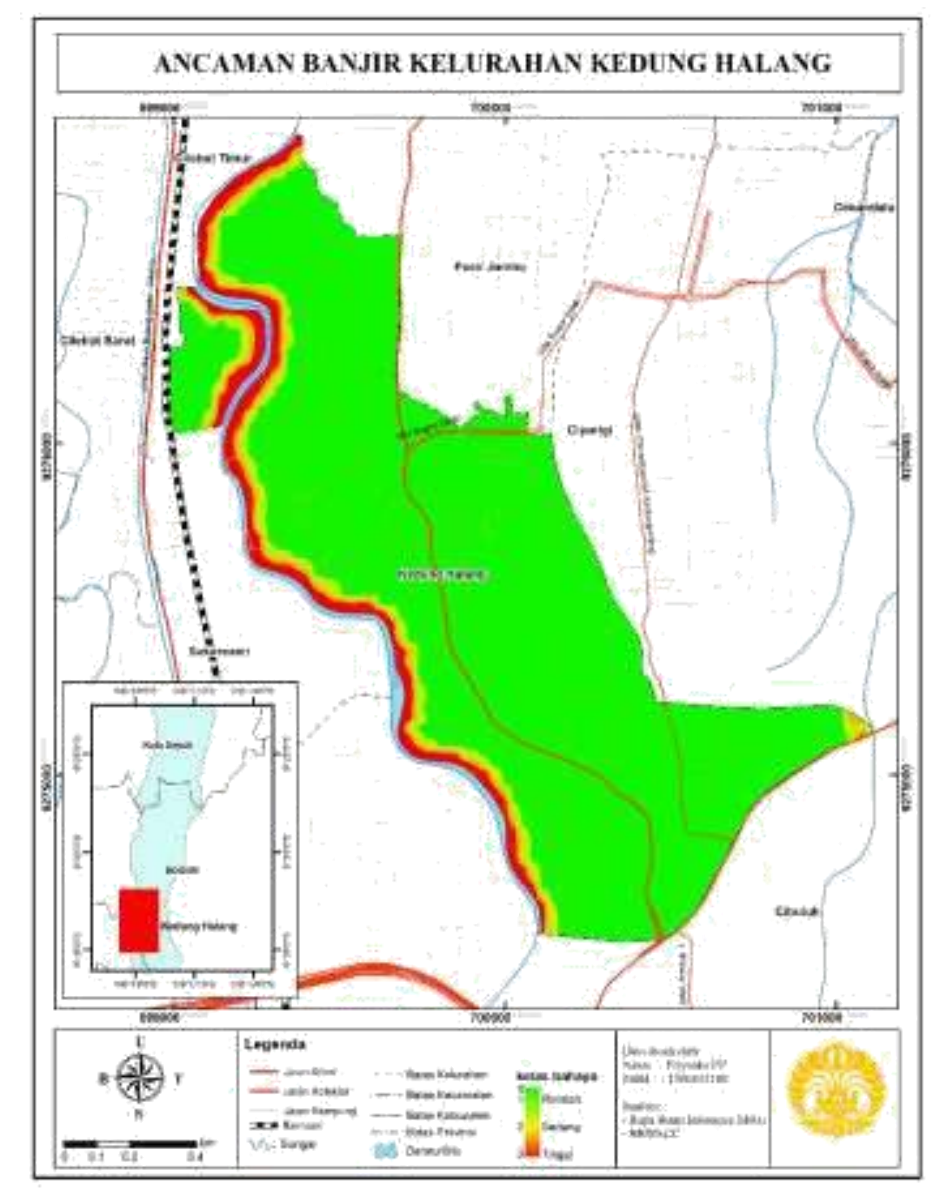

Gambar 4. Peta Ancaman Bencana Banjir di Kelurahan Kedunghalang Sumber: Hasil Olahan Penulis, 2019 


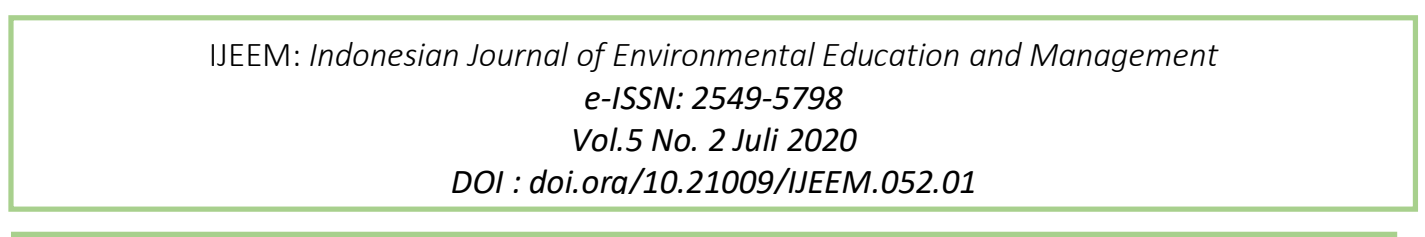

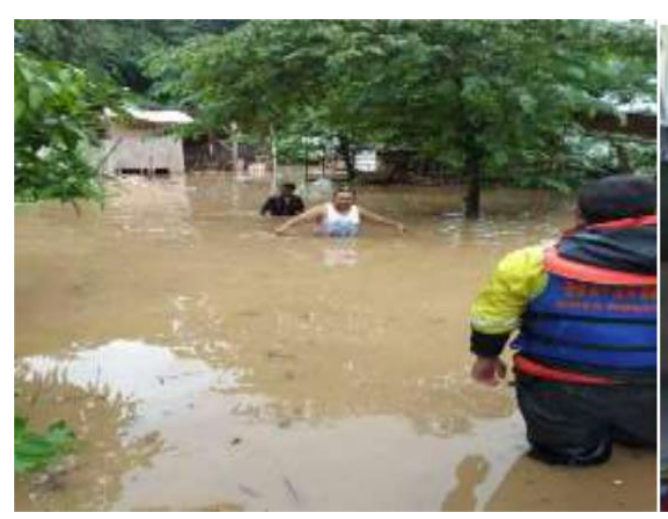

(a)

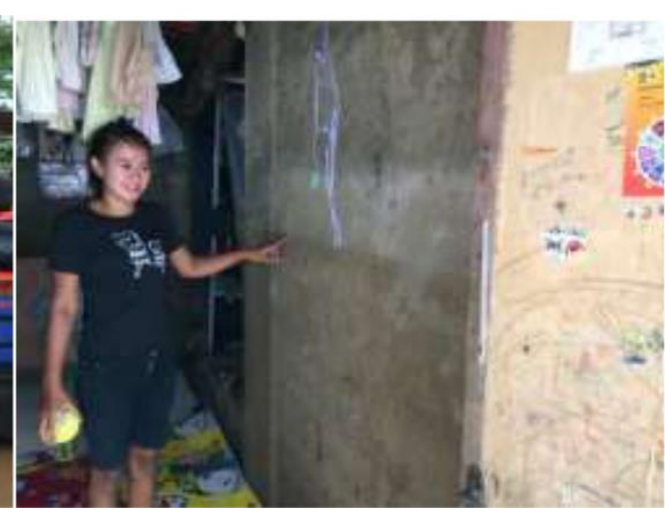

(b)

Gambar 5. (a) Kondisi Banjir di Kelurahan Kedunghalang pada tanggal 05 Februari 2018 (b) Bukti bekas terjadinya banjir di Kelurahan Kedunghalang Sumber: Dokumentasi BPBD Kota Bogor, 2018

Hasil perhitungan indeks ancaman bencana banjir Kelurahan Tanah Sareal yang merupakan salah satu kelurahan yang berada di segmen tengah DAS Ciliwung memiliki tiga kelas bahaya banjir yaitu rendah, sedang dan tinggi. Seluas 2,5 ha atau 2,3\% wilayah Kelurahan Tanah Sareal berada di kelas bahaya rendah, seluas 2,4 ha atau 2,2\% wilayah Kelurahan Tanah Sareal berada di kelas bahaya sedang dan untuk kelas bahaya tinggi seluas 5,6 ha atau 5,1\% seperti yang digambarkan pada Gambar 6. Pada tanggal 05 Februari 2018 berdasarkan data dari BPBD Kota Bogor, Kelurahan Tanah Sareal juga terdampak banjir dengan ketinggian banjir $20 \mathrm{~cm}$ sampai dengan $150 \mathrm{~cm}$. 


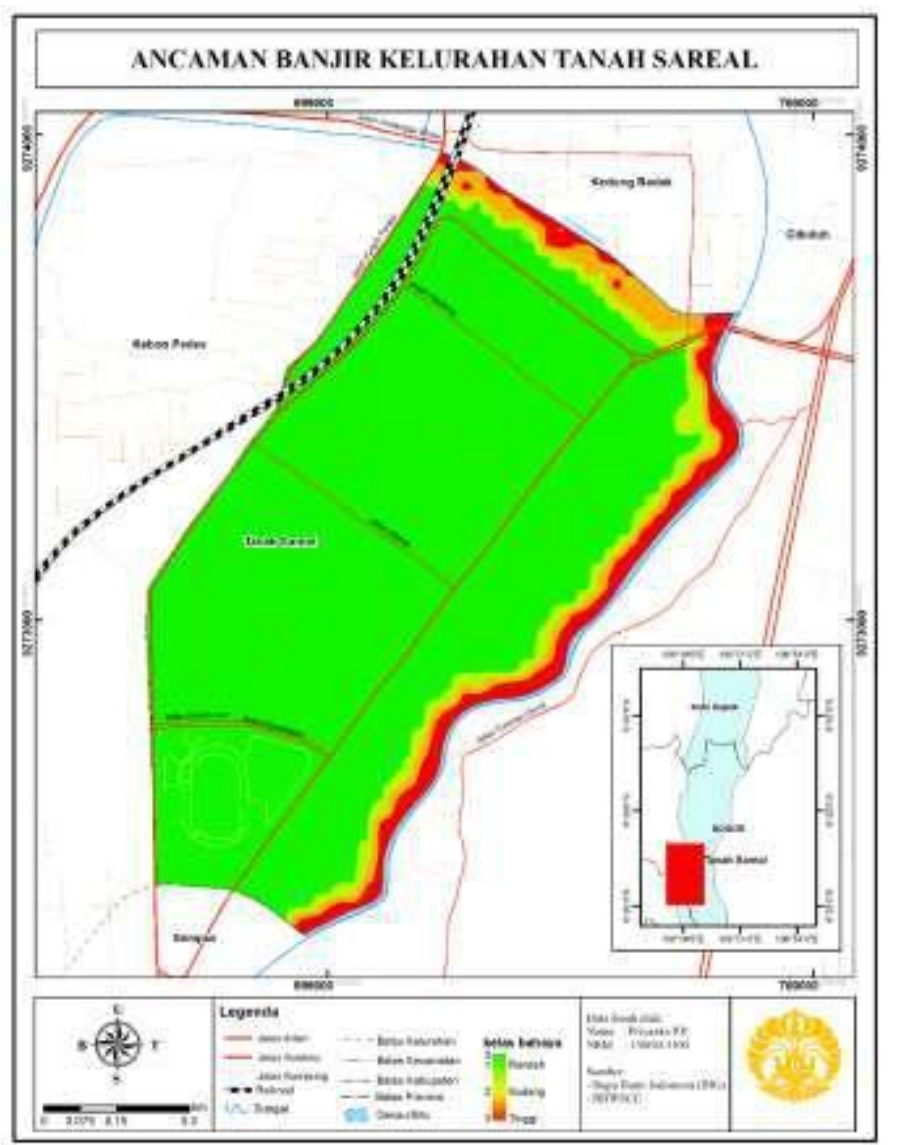

Gambar 6. Peta Ancaman Bencana Banjir di Kelurahan Tanah Sareal Sumber: Hasil Olahan Penulis, 2019

Wilayah yang berada di kelas bahaya tinggi merupakan daerah yang berjarak $<300$ meter dari sungai dengan kemiringan lereng $<15 \%$ sehingga dapat menyebabkan banjir dengan kedalaman lebih dari 1,5 m. Banjir di segmen tengah DAS Ciliwung yaitu Kelurahan Kedunghalang dan Kelurahan Tanah Sareal diakibatkan luapan sungai Ciliwung karena tingginya curah hujan di wilayah hulu sungai yang menyebabkan Bendung Katulampa Siaga 1 (bencana). Saat Bendung Katulampa dilaporkan Siaga 1 maka 30 menit kemudian Kelurahan Kedunghalang akan terdampak banjir.

Pada segmen hilir DAS Ciliwung yaitu Kelurahan Balekambang dan Kelurahan Srengseng Sawah, terdapat tiga kelas bahaya banjir yaitu rendah, sedang dan tinggi. Berdasarkan hasil perhitungan indeks ancaman kelas bahaya rendah seluas 5,7 ha atau 3,4\% dari luas Kelurahan Balekambang. Kelas bahaya sedang seluas 3,4 ha atau 2\% dari luas Kelurahan Balekambang dan 14,8 ha atau 8,8\% dari luas Kelurahan Balekambang berada di kelas bahaya tinggi. Peta ancaman banjir Kelurahan Balekambang sesuai dengan Gambar 7. 


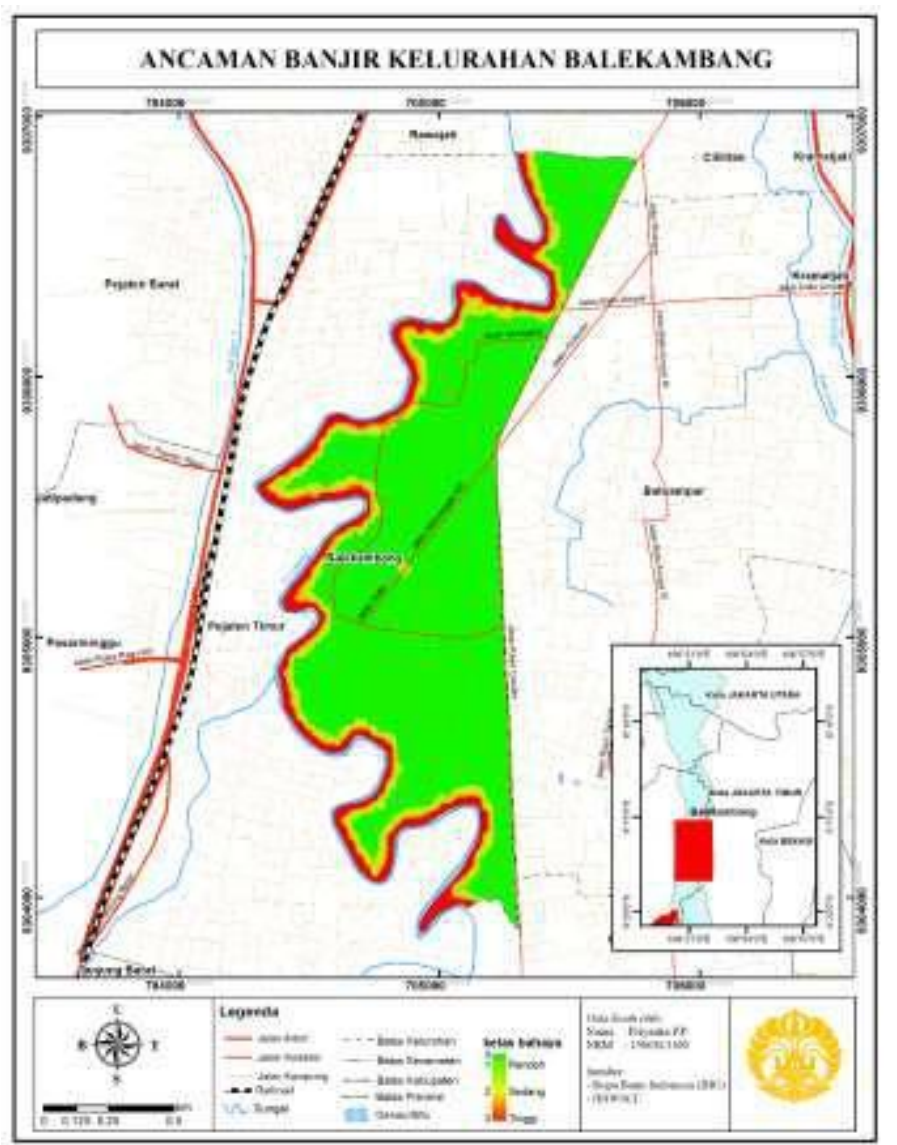

Gambar 7. Peta Ancaman Bencana Banjir di Kelurahan Balekambang Sumber: Hasil Olahan Penulis, 2019

Sedangkan untuk Kelurahan Srengseng Sawah, kelas bahaya rendah seluas 1,4 ha atau $0,2 \%$ dari luas wilayah Kelurahan Srengseng Sawah. Seluas 0,8 ha atau $0,1 \%$ luas wilayah Kelurahan Srengseng Sawah berada di kelas bahaya sedang dan 24,8 ha atau 3,9\% dari luas wilayah Kelurahan Srengseng Sawah berada di kelas bahaya tinggi Gambar 4.7. Berdasarkan hasil studi literatur, pada tanggal 05 Februari 2018 Kelurahan Balekambang dan Srengseng Sawah tercatat mengalami bencana banjir dengan ketinggian banjir mencapai 3m (kelas indeks tinggi). Banjir yang terjadi di Kelurahan Balekambang dan Kelurahan Srengseng Sawah diakibatkan luapan Sungai Ciliwung, dan area yang mempunyai ancaman bencana banjir adalah area pemukiman penduduk yang berada di sempadan Sungai Ciliwung. Banjir di segmen hilir DAS Ciliwung akibat tinggianya curah hujan di wilayah hulu DAS Ciliwung, hal tersebut dapat dilihat dari status Siaga Bendung Katulampa. Saat Bendung Katulampa dilaporkan Siaga 1 maka 6 jam kemudian Kelurahan Balekambang dan Srengseng Sawah akan terdampak banjir. 


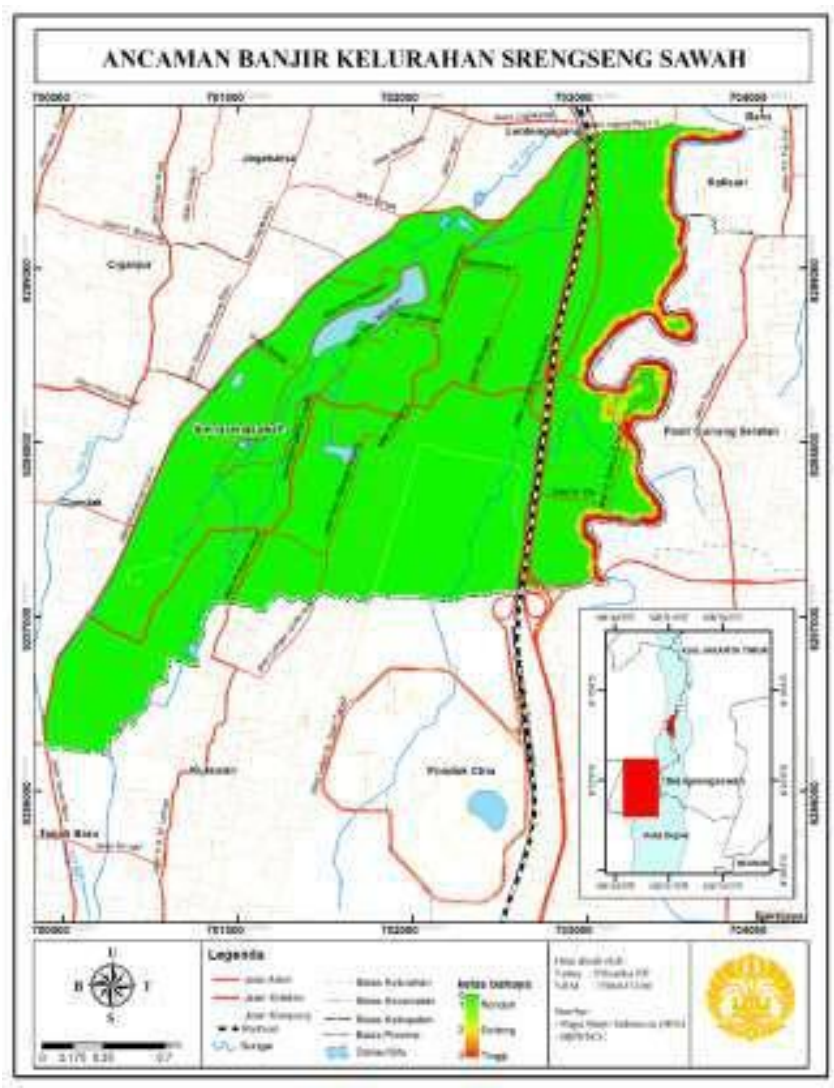

Gambar 8. Peta Ancaman Bencana Banjir di Kelurahan Srengseng Sawah Sumber: Hasil Olahan Penulis, 2019

2) Kerentanan Sosial dan Ekonomi

Hasil perhitungan indeks kerentanan sosial dan ekonomi di Kelurahan Kedunghalang menunjukkan kerentanan tinggi (Gambar 9.). Total penduduk sebanyak 20.643 jiwa dengan luas wilayah 192 ha dengan kepadatan penduduk 107.8 jiwa/ha membuat Kelurahan Kedunghalang rentan terhadap bencana. Rasio jenis kelamin di Kelurahan Kedunghalang sebesar 105 (Tabel 3.) 
Tabel 3. Indeks Kerentanan Bencana Banjir Segmen Tengah DAS Ciliwung

\begin{tabular}{|c|c|c|c|c|c|c|c|c|}
\hline Segmen & Kelurahan & $\begin{array}{c}\text { Total } \\
\text { Penduduk }\end{array}$ & $\begin{array}{c}\text { Umur } \\
\text { Rentan }\end{array}$ & $\begin{array}{c}\text { Rasio } \\
\text { Kemiskinan }\end{array}$ & $\begin{array}{c}\text { Rasio Jenis } \\
\text { Kelamin }\end{array}$ & Disabilitas & $\begin{array}{c}\text { Indeks } \\
\text { Kerentanan }\end{array}$ & $\begin{array}{c}\text { Kelas } \\
\text { Kerentanan }\end{array}$ \\
\hline \multirow{2}{*}{ Tengah } & Kedung Halang & 20643 & 5089 & 0.56 & 105 & 0 & 0.783 & 3 \\
\cline { 2 - 9 } & Tanah Sareal & 9194 & 3275 & 6.08 & 97 & 0 & 0.833 & 3 \\
\hline
\end{tabular}

Sumber: Hasil olahan penulis, 2019

Selain padat penduduk, masih banyak masyarakat di Kelurahan Kedunghalang bertempat tinggal $<500 \mathrm{~m}$ dari sungai Ciliwung. Selain itu, hasil observasi langsung di lapangan menunjukan bahwa sebagian besar $(71 \%)$ mata pencaharian penduduk di Kelurahan Kedunghalang yang tinggal di wilayah rawan banjir adalah buruh dan $57 \%$ jenjang pendidikan terakhir penduduk di wilayah rawan banjir yaitu Sekolah Dasar (SD), 29\% pendidikan terakhir SMP dan 14\% pendidikan terakhir SMA. Mata pencaharian yang tidak tetap dan pendidikan terakhir yang masih rendah dapat mengingkatkan kerentanan ekonomi.

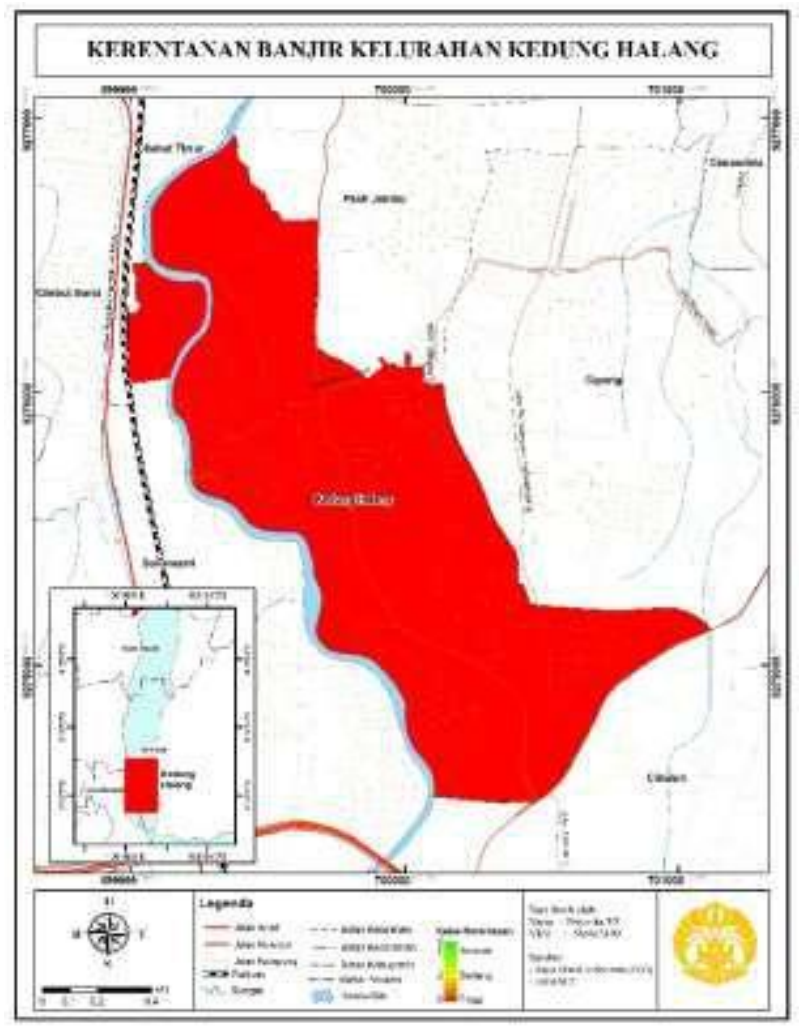

Gambar 9. Peta Kerentanan Bencana Banjir di Kelurahan Kedunghalang Sumber: Hasil Olahan Penulis, 2019 
Kelurahan Tanah Sareal dengan jumlah penduduk sebanyak 9.194 jiwa dengan luas area 105 ha dan kepadatan penduduk 88 jiwa/ha membuat kelurahan Tanah Sareal berada di kelas kerentanan banjir tinggi (Gambar 10.). Sama seperti Kelurahan Kedunghalang, di Kelurahan Tanah Sareal masih banyak didapati penduduk yang bermukim <500 m dari sungai. Sebagian besar masyarakat yang bermukim berbatasan langsung dengan Sungai Ciliwung bermatapencaharian sebagai buruh dan ibu rumah tangga.

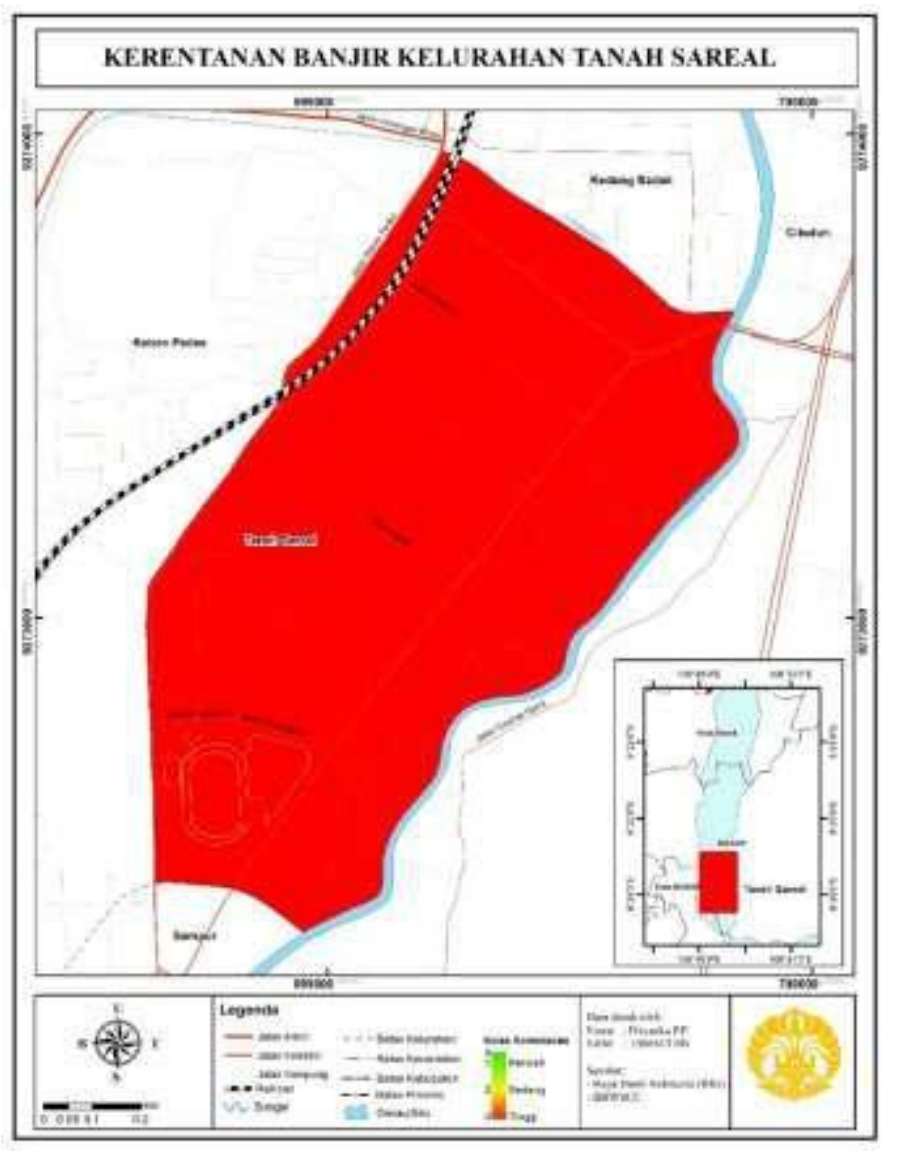

Gambar 10. Peta Kerentanan Bencana Banjir di Kelurahan Tanah Sareal Sumber: Hasil Olahan Penulis, 2019

Hasil perhitungan indeks kerentanan sosial dan ekonomi di Kelurahan Balekambang menunjukkan kerentanan tinggi (Gambar 12). Total penduduk sebanyak 32.083 jiwa dan luas wilayah 165 ha dengan kepadatan penduduk 194 jiwa/ha membuat Kelurahan Balekambang memiliki kerentanan sosial yang tinggi. Rasio jenis kelamin di Kelurahan Balekambang sebesar 104. Selain padat penduduk, masih banyak masyarakat di Kelurahan Balekambang bertempat tinggal $<500 \mathrm{~m}$ dari sungai Ciliwung seperti yang ditunjukkan pada Gambar 11 . 


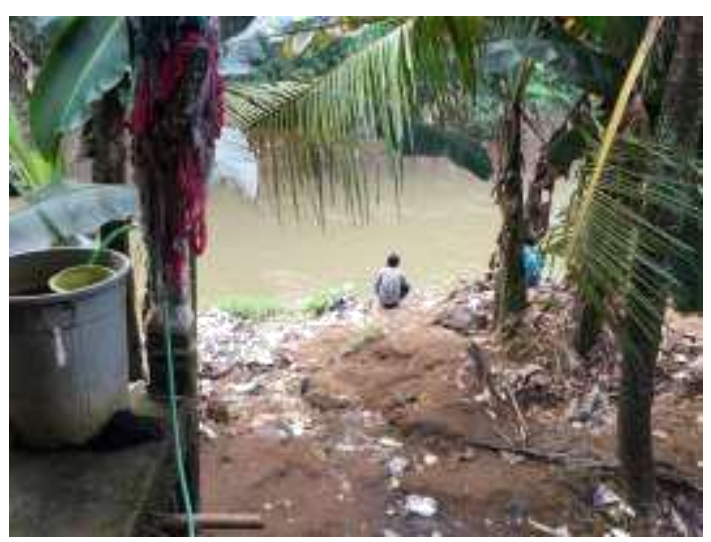

Gambar 11. Salah Satu Rumah Penduduk di Kelurahan Balekambang Sumber: Hasil Survey, 2019

Selain itu, hasil observasi langsung di lapangan menunjukan bahwa sebagian besar (65\%) mata pencaharian penduduk di Kelurahan Balekambang yang tinggal di wilayah rawan banjir adalah wiraswasta dan $52 \%$ penduduk di wilayah rawan banjir pendidikan terakhir Sekolah Menengah Atas (SMA). Mata pencaharian yang tidak tetap dan pendidikan terakhir yang masih rendah dapat mengingkatkan kerentanan ekonomi.

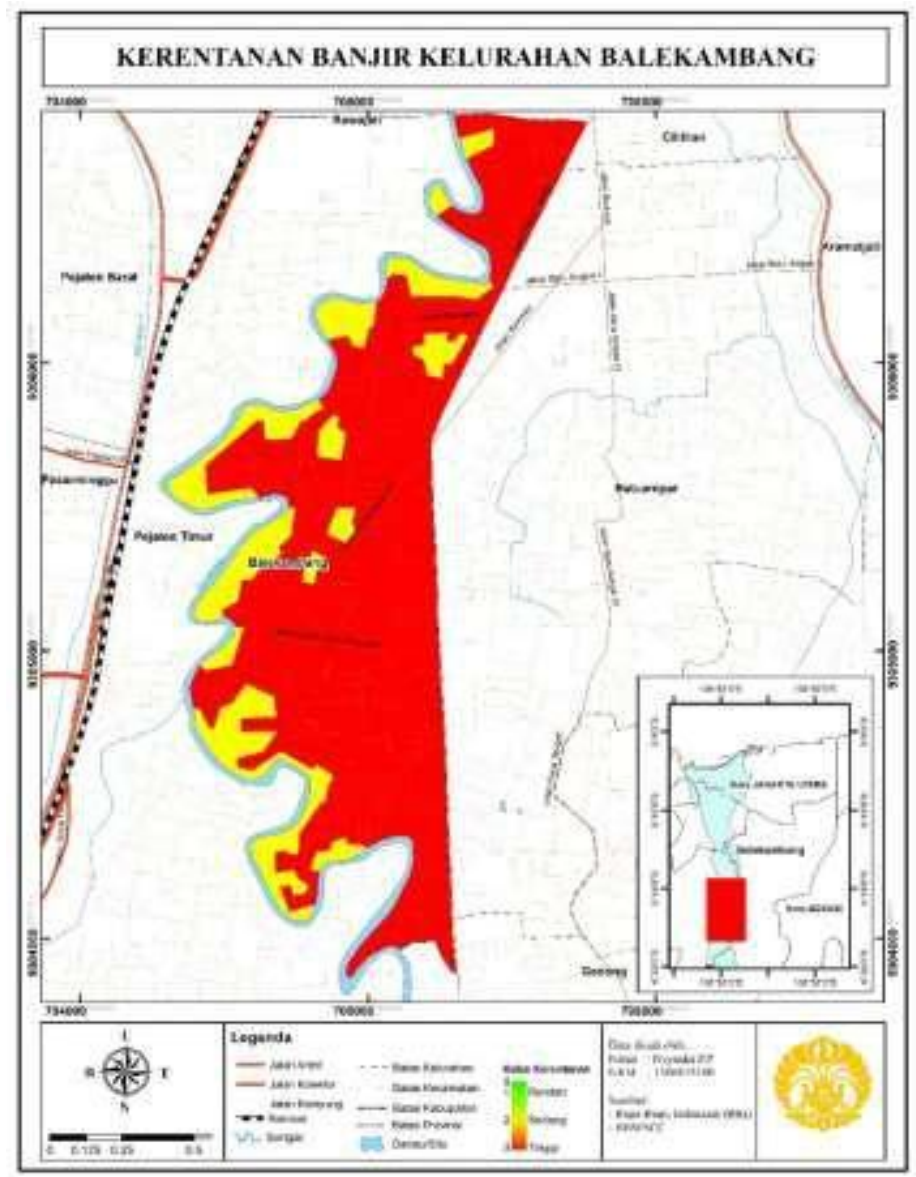


Gambar 12. Peta Kerentanan Bencana Banjir di Kelurahan Balekambang Sumber: Hasil Olahan Penulis, 2019

Pada Gambar 14. menunjukkan tingkat kerentanan di Kelurahan Srengseng Sawah. Berdasarkan Hasil perhitungan indeks kerentanan sosial dan ekonomi di Kelurahan Srengseng Sawah menunjukkan kerentanan tinggi. Total penduduk sebanyak 73.493 jiwa dan luas wilayah 675 ha dengan kepadatan penduduk 109 jiwa/ha membuat Kelurahan Srengseng Sawah memiliki kerentanan sosial yang tinggi. Rasio jenis kelamin di Kelurahan Srengseng Sawah sebesar 102 (Tabel 4.).

Tabel 4. Indeks Kerentanan Bencana Banjir Segmen Hilir DAS Ciliwung

\begin{tabular}{|c|c|c|c|c|c|c|c|c|}
\hline Segmen & Kelurahan & $\begin{array}{c}\text { Total } \\
\text { Penduduk }\end{array}$ & $\begin{array}{c}\text { Umur } \\
\text { Rentan }\end{array}$ & $\begin{array}{c}\text { Rasio } \\
\text { Kemiskinan }\end{array}$ & $\begin{array}{c}\text { Rasio Jenis } \\
\text { Kelamin }\end{array}$ & Disabilitas & $\begin{array}{c}\text { Indeks } \\
\text { Kerentanan }\end{array}$ & $\begin{array}{c}\text { Kelas } \\
\text { Kerentanan }\end{array}$ \\
\hline \multirow{2}{*}{ Hilir } & Balekambang & 32083 & 5089 & 2.86 & 104 & 9 & 0.783 & 3 \\
\cline { 2 - 9 } & Srengseng Sawah & 73493 & 3275 & 0.21 & 102 & 5 & 0.783 & 3 \\
\hline
\end{tabular}

Sumber: Hasil olahan penulis, 2019

Padatnya penduduk menyebabkan banyak penduduk yang menempati/bermukim di pinggir Sungai Ciliwung seperti yang ditunjukkan pada Gambar 13.

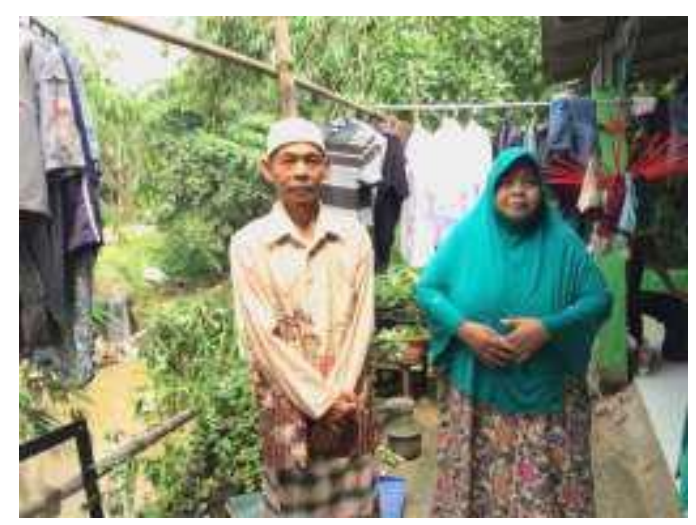

Gambar 13. Salah Satu Rumah Penduduk di Kelurahan Srengseng Sawah Sumber: Hasil Survey, 2019 
Hasil observasi langsung di lapangan menunjukan bahwa sebagian besar (32\%) mata pencaharian penduduk di Kelurahan Srengseng Sawah yang tinggal di wilayah rawan banjir adalah swasta dan $40 \%$ penduduk di wilayah rawan banjir pendidikan terakhir Sekolah Menengah Atas (SMA). Mata pencaharian yang tidak tetap dan pendidikan terakhir yang masih rendah dapat mengingkatkan kerentanan ekonomi.

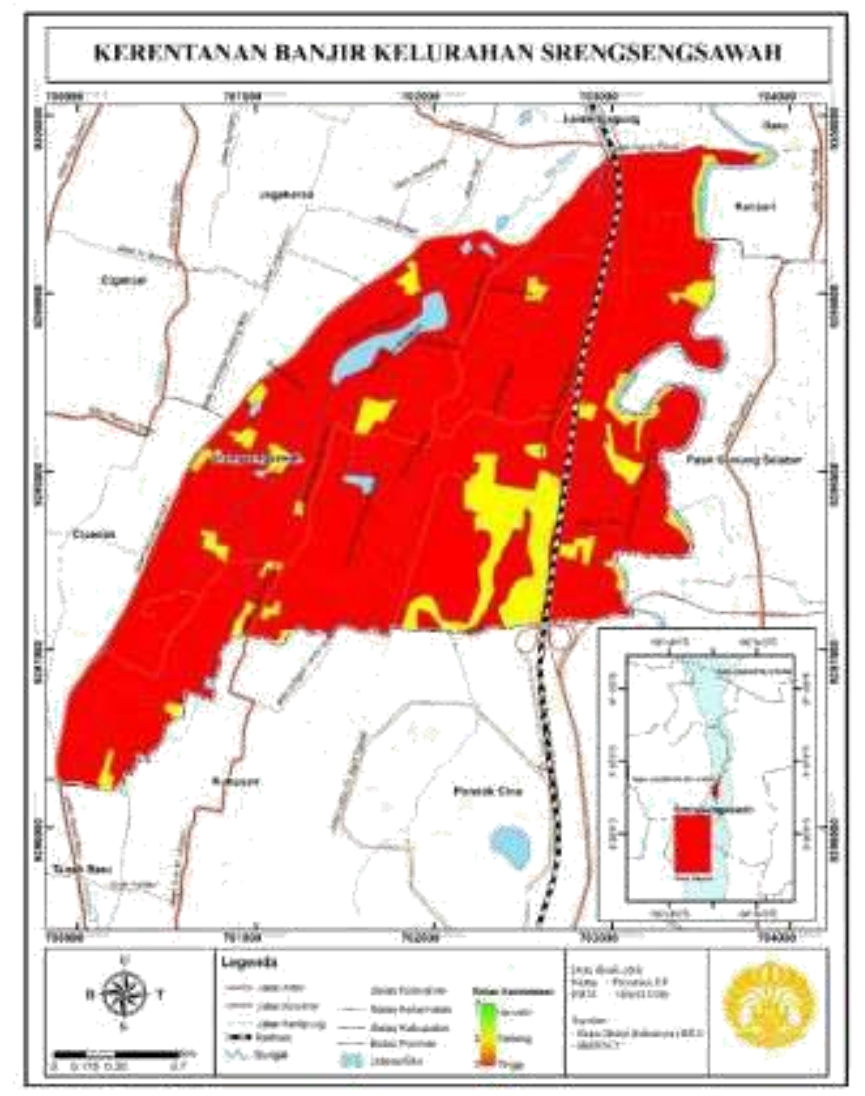

Gambar 14. Peta Kerentanan Bencana Banjir di Kelurahan Srengseng Sawah Sumber: Hasil Olahan Penulis, 2019

Pada penelitian ini kajian pengurangan risiko bencana banjir di DAS Ciliwung, mengarah pada kondisi sosial ekonomi masyarakat di segmen tengah dan hilir DAS Ciliwung. Kondisi sosial ekonomi masyarakat mempengaruhi kerentanan dan kapasitas dalam pengurangan risiko bencana. Mayoritas masyarakat yang berada di segmen tengah dan hilir DAS Ciliwung telah bermukim selama lebih dari 20 tahun dengan persentase sebesar $52 \%$. Persentase tingkat pendidikan masyarakat segmen tengah dan hilir DAS Ciliwung terbesar adalah Sekolah Menengah Atas (SMA) dengan persentase sebesar 45\%. Selain itu mayoritas pekerjaan masyarakat adalah lainnya (buruh dan ibu rumah tangga) sebesar $40 \%$. 
Hasil observasi juga menunjukkan bahwa pertumbuhan jumlah penduduk yang pesat diikuti oleh meningkatnya kebutuhan pokok manusia, salah satunya yaitu tempat tinggal. Berdasarkan data yang diperoleh $99 \%$ masyarakat yang terdampak banjir di segmen tengah dan hilir DAS Ciliwung bertempat tinggal $<500 \mathrm{~m}$ dari sungai.

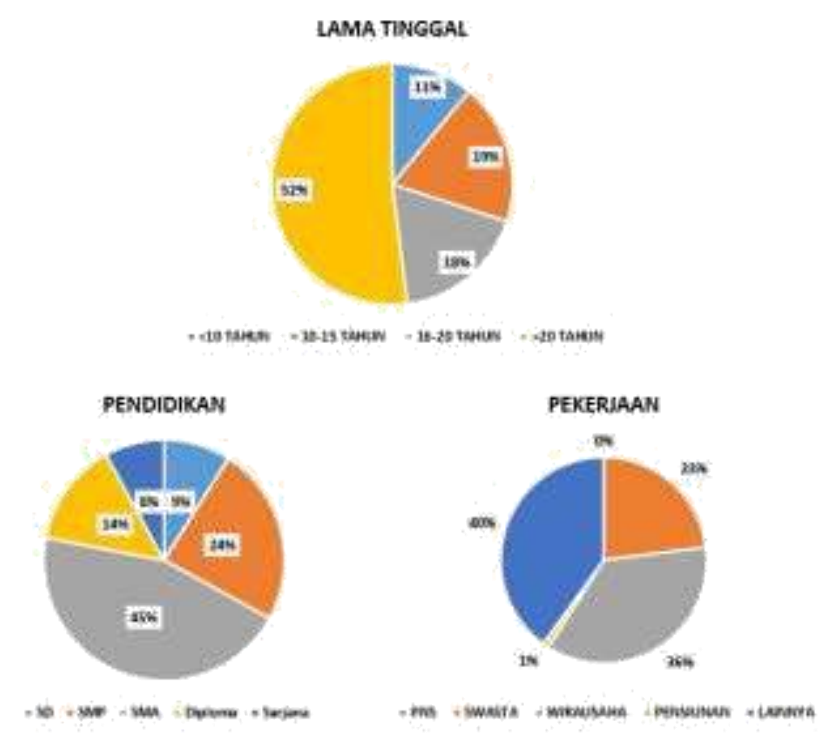

Gambar 15. Data Responden

Sumber: Hasil Olahan Penulis, 2019

3) Kapasitas Masyarakat dan Daerah

Tingkat kesiapsiagaan masyarakat DAS Ciliwung dalam menghadapi kemungkinan terjadinya bencana banjir secara umum dapat direfleksikan dalam bentuk indeks gabungan rumah tangga (household joint score index). Indeks tersebut merupakan gabungan dari 4 parameter yaitu indeng pengetahuan, indeks rencana kesiapsiagaan, indeks sistem peringatan bencana dan indeks mobilisasi sumber daya.

Secara umum hasil perhitungan yang dilakukan peneliti menunjukkan bahwa indeks gabungan kesiapsiagaan rumah tangga masih menunjukkan angka yang rendah, yaitu 53 (Tabel 5.). Dalam klasifikasi kesiapsiagaan, indeks tersebut dapat dikelompokkan ke dalam klasifikasi kurang siap. Dari 4 parameter yang digunakan ternyata kontribusi indeks yang cukup besar terletak pada indeks pengetahuan dan sistem peringatan bencana, dimana indeks pengetahuan sendiri telah mencapai 76 dan indeks sistem peringatan bencana mencapai 63. Indeks pengetahuan dan sistem 
peringatan bencana tersebut apabila dimasukkan dalam klasifikasi kesiapsiagaan sudah termasuk siap. Sedangkan yang berkontribusi menjatuhkan angka indeks kesiapsiagaan masyarakat di DAS Ciliwung adalah indeks rencana kesiapsiagaan dan indeks mobilisasi sumber daya. Total skor nilai indeks rencana kesiapsiagaan hanya sebesar 33 dan indeks mobilisasi sumberdaya sebesar 31. Apabila dimasukkan dalam klasifikasi kesiapsiagaan indeks rencana dan indeks mobilisasi sumberdaya masuk ke dalam kategori belum siap. Fakta ini menunjukkan bahwa rencana kesiapsiagaan dan mobilisasi sumber daya masyarakat di DAS Ciliwung masih lemah.

Tabel 5. Nilai Indeks Kesiapsiagaan Masyarakat di DAS Ciliwung

\begin{tabular}{|c|l|l|l|l|l|c|c|}
\hline \multirow{2}{*}{ Segmen } & \multicolumn{1}{|c|}{ Kelurahan } & P & RK & PB & MS & $\begin{array}{c}\text { Indeks } \\
\text { Kesiapsiagaan }\end{array}$ & $\begin{array}{c}\text { Kategori } \\
\text { Kesiapsiagaan }\end{array}$ \\
\hline \multirow{2}{*}{ Hilir } & Bale Kambang & 79 & 34 & 69 & 34 & 56 & Hampir Siap \\
\cline { 2 - 8 } & Srengseng Sawah & 82 & 39 & 77 & 42 & 61 & Hampir Siap \\
\hline \multirow{2}{*}{ Tengah } & Kedung Halang & 76 & 35 & 59 & 31 & 54 & Kurang Siap \\
\cline { 2 - 8 } & Tanah Sareal & 65 & 22 & 48 & 18 & 42 & Kurang Siap \\
\hline \multirow{2}{*}{} & RATA-RATA & $\mathbf{7 6}$ & $\mathbf{3 3}$ & $\mathbf{6 3}$ & $\mathbf{3 1}$ & $\mathbf{5 3}$ & Kurang Siap \\
\hline
\end{tabular}

Sumber: Hasil Analisis

Kapasitas daerah dihitung menggunakan Indeks Kapasitas daerah berdasarkan penguatan kebijakan dan kelembagaan, pengkajian risiko dan perencanaan terpadu, pengembangan system informasi, diklat dan logistic, penanganan tematik kawasan rawan bencana, peningkatan efektivitas pencegahan dan mitigasi bencana, perkuatan kesiapsiagaan dan penanganan darurat serta pengembangan system pemulihan bencana.

Berdasarkan hasil analisis dan penggabungan antara kapasitas daerah Provinsi Jawa Barat dan Provinsi DKI Jakarta, maka nilai indeks kapasitas daerah di DAS Ciliwung sebesar $0.45 \%$ berada di level tingkat kapasitas daerah sedang. Dengan nilai prioritas tertinggi yaitu prioritas pengkajian risiko dan perencanaan terpadu dengan nilai indeks sebesar $1 \%$. BPBD Provinsi DKI Jakarta, BPBD Provinsi Jawa Barat yang didalamnya termasuk BPBD Kota Bogor sudah memiliki dan menyusun dokumen rencana penanggulangan bencana serta sudah melakukan kajian risiko bencana. Pada pengembangan system informasi, BPBD Provinsi Jawa Barat dan BPBD Kota Bogor sudah memiliki Pusdalops, sedangan BPBD DKI Jakarta walaupun belum memiliki Pusdalops, mekanisme komunikasi lintas pemangku kepentingan 
untuk memperkuat upaya pengurangan risiko bencana dilakukan oleh UPT. Pusdatin BPBD DKI Jakarta.

Pada prioritas penanganan tematik Kawasan rawan bencana terdapat indikator sekolah dan madrasah aman bencana. Sekolah dan madrasah aman yang telah disosialisasikan oleh BPBD DKI Jakarta, BPBD Jawa Barat dan BPBD Kota Bogor belum mencapai target 75\% dari total jumlah sekolah/madrasah.

Untuk indikator pemantauan berkala hulu sungai pada prioritas peningkatan efektivitas pencegahan dan mitigasi bencana, BPBD DKI Jakarta telah inisiatif untuk terlibat secara lintas administrasi dalam pemantauan hulu sungai yang berada di Provinsi Jawa Barat. Nilai indeks prioritas peningkatan efektivitas pencegahan dan mitigasi bencana masih rendah dikarenakan walaupun sudah ada upaya yang dilakukan baik oleh BPBD DKI Jakarta, BPBD Jawa Barat maupun BPBD Kota Bogor, upaya yang telah dilakukan tersebut belum diukur efektivitasnya terhadap masyarakat dan pengurangan risiko bencana banjir.

Tabel 6. Indeks Kapasitas Daerah di DAS Ciliwung

\begin{tabular}{|c|c|c|c|c|c|}
\hline NO. & PRIORITAS & $\begin{array}{l}\text { INDEKS } \\
\text { PRIORITAS }\end{array}$ & $\begin{array}{c}\text { INDEKS } \\
\text { KAPASITAS } \\
\text { DAERAH }\end{array}$ & $\begin{array}{c}\text { TINGKAT } \\
\text { KAPASITAS } \\
\text { DAERAH }\end{array}$ & SKOR \\
\hline 1 & $\begin{array}{l}\text { Perkuatan Kebijakan dan } \\
\text { Kelembagaan }\end{array}$ & 0.76 & \multirow{7}{*}{0.45} & \multirow{7}{*}{ SEDANG } & \multirow{7}{*}{1.4081} \\
\hline 2 & $\begin{array}{l}\text { Pengkajian Risiko dan } \\
\text { Perencanaan Terpadu }\end{array}$ & 1.00 & & & \\
\hline 3 & $\begin{array}{l}\text { Pengembangan Sistem } \\
\text { Informasi, Diklat dan Logistik }\end{array}$ & 0.81 & & & \\
\hline 4 & $\begin{array}{l}\text { Penanganan Tematik } \\
\text { Kawasan Rawan Bencana }\end{array}$ & 0.62 & & & \\
\hline 5 & $\begin{array}{l}\text { Peningkatan Efektivitas } \\
\text { Pencegahan dan Mitigasi } \\
\text { Bencana }\end{array}$ & 0.24 & & & \\
\hline 6 & $\begin{array}{l}\text { Perkuatan Kesiapsiagaan dan } \\
\text { Penanganan Darurat Bencana }\end{array}$ & 0.39 & & & \\
\hline 7 & $\begin{array}{l}\text { Pengembangan Sistem } \\
\text { Pemulihan Bencana }\end{array}$ & 0.26 & & & \\
\hline
\end{tabular}

Sumber: Hasil Analisis

\section{4) Analisis Risiko Bencana Banjir}

Berdasarkan analisis ancaman bencana banjir di segmen tengah DAS Ciliwung yaitu di Kelurahan Kedunghalang dan Kelurahan Tanah Sareal menunjukkan bahwa indeks ancaman bencana banjir dan indeks kerentanan sosial ekonomi berada pada kategori tinggi. Sedangkan 
untuk indeks kapasitas berada pada kategori rendah (kurang siap). Untuk mengetahui tingkat kapasitas dapat dilihat pada Gambar 16.

\begin{tabular}{|c|c|c|c|c|}
\hline \multirow{2}{*}{\multicolumn{2}{|c|}{ Tingkat Kapasitas }} & \multicolumn{3}{|c|}{ Indeks Kapasitas } \\
\hline & & Tinggi & Sedang & Rendah \\
\hline \multirow{3}{*}{ 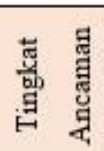 } & Rendah & & & \\
\hline & Sedang & & & \\
\hline & Tinggi & & & Rendah \\
\hline
\end{tabular}

(a)

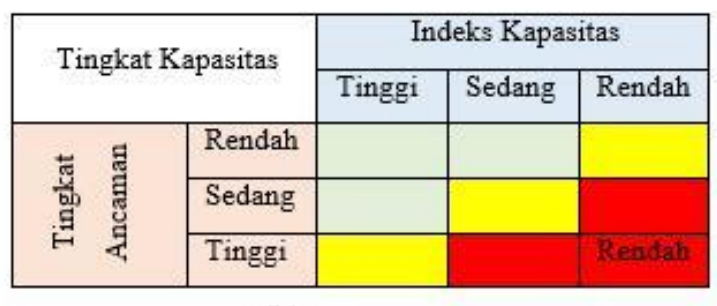

(b)

Gambar 16.

(a) Matriks Tingkat Kapasitas Kelurahan Kedunghalang

(b) Matriks Tingkat Kapasitas Kelurahan Tanah Sareal

Tingkat kapasitas diperoleh dari penggabungan tingkat ancaman dan indeks kapasitas. Berdasarkan matriks penentuan tingkat kapasitas maka didapatkan bahwa tingkat kapasitas di Kelurahan Kedunghalang dan Tanah Sareal kategori rendah. Setelah penetuan tingkat kapasitas adalah penentuan tingkat risiko bencana bannjir. Tingkat risiko bencana ditentukan dengan menggabungkan tingkat kerentanan dengan tingkat kapasitas. Untuk mengetahui tingkat risiko bencana banjir dapat dilihat pada Gambar 17.

\begin{tabular}{|c|c|c|c|c|}
\hline \multirow{2}{*}{\multicolumn{2}{|c|}{ Tingkat Risiko }} & \multicolumn{3}{|c|}{ Tingkat Kapasitas } \\
\hline & & Tinggi & Sedang & Rendah \\
\hline \multirow{3}{*}{ 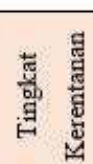 } & Rendah & & & \\
\hline & Sedang & & & \\
\hline & Tinggi & & & Tinggi \\
\hline
\end{tabular}

(a)

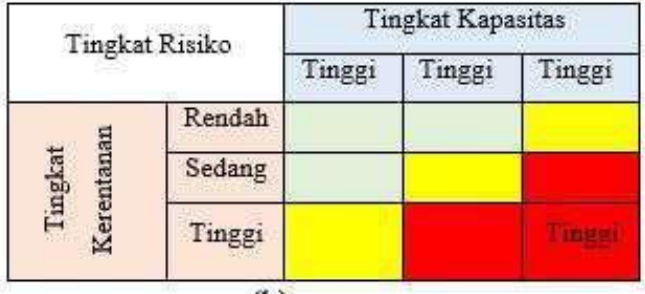

(b)

Gambar 17.

(a) Matriks Tingkat Risiko Bencana Banjir Kelurahan Kedunghalang

(b) Matriks Tingkat Risiko Bencana Banjir Kelurahan Tanah Sareal

Berdasarkan matriks penentuan tingkat risiko bencana banjir, menunjukkan bahwa Kelurahan Kedunghalang dan Kelurahan Tanah Sareal berada di kategori tinggi. Hal tersebut dikarenakan kapasitas masyarakat di segmen tengah yang rendah dan kerentanan sosial ekonomi yang tinggi pada segmen tengah. 
Berdasarkan analisis ancaman bencana banjir di segmen hilir DAS Ciliwung yaitu di Kelurahan Balekambang dan Kelurahan Srengseng Sawah menunjukkan bahwa indeks ancaman bencana banjir dan indeks kerentanan sosial ekonomi berada pada kategori tinggi. Sedangkan untuk indeks kapasitas berada pada kategori sedang (hampir siap). Untuk mengetahui tingkat kapasitas dapat dilihat pada Gambar 18.

\begin{tabular}{|c|c|c|c|c|}
\hline \multirow{2}{*}{\multicolumn{2}{|c|}{ Tingkat Kapasitas }} & \multicolumn{3}{|c|}{ Indeks Kapasitas } \\
\hline & & Tinggi & Sedang & Rendah \\
\hline \multirow{3}{*}{ 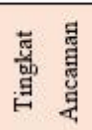 } & Rendah & & & \\
\hline & Sedang & & & \\
\hline & Tinggi & & Rendah & \\
\hline
\end{tabular}

(a)

\begin{tabular}{|c|c|c|c|c|}
\hline \multirow{2}{*}{\multicolumn{2}{|c|}{ Tingkat Kapasitas }} & \multicolumn{3}{|c|}{ Indeks Kapasitas } \\
\hline & & Tinggi & Sedang & Rendah \\
\hline \multirow{3}{*}{ 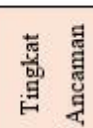 } & Rendah & & & \\
\hline & Sedang & & & \\
\hline & Tinggi & & Rendah & \\
\hline
\end{tabular}

(b)

Gambar 18.

(a) Matriks Tingkat Kapasitas Kelurahan Balekambang (b) Matriks Tingkat Kapasitas Kelurahan Srengseng Sawah

Berdasarkan matriks penentuan tingkat kapasitas maka didapatkan bahwa tingkat kapasitas di Kelurahan Balekambang dan Srengseng Sawah kategori rendah. Setelah penetuan tingkat kapasitas adalah penentuan tingkat risiko bencana bannjir. Tingkat risiko bencana ditentukan dengan menggabungkan tingkat kerentanan dengan tingkat kapasitas. Untuk mengetahui tingkat risiko bencana banjir dapat dilihat pada Gambar 19.

\begin{tabular}{|c|c|c|c|c|}
\hline \multirow{2}{*}{\multicolumn{2}{|c|}{ Tingkat Risiko }} & \multicolumn{3}{|c|}{ Tingkat Kapasitas } \\
\hline & & Tinggi & Sedang & Rendah \\
\hline \multirow{3}{*}{ 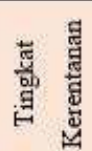 } & Rendah & & & \\
\hline & Sedang & & & \\
\hline & Tinggi & & & Imingi \\
\hline
\end{tabular}

(a)

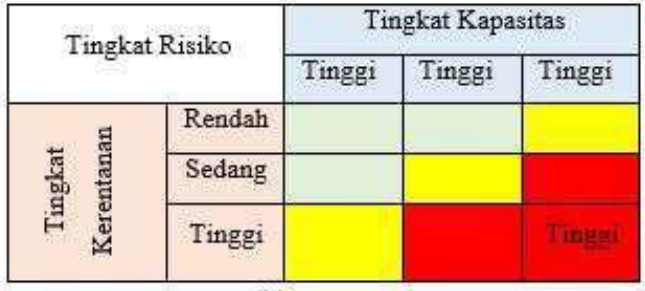

(b)

Gambar 19.

(a) Matriks Tingkat Risiko Bencana Banjir Kelurahan Balekambang (b) Matriks Tingkat Risiko Bencana Banjir Kelurahan Srengseng Sawah

Berdasarkan matriks penentuan tingkat risiko bencana banjir, menunjukkan bahwa Kelurahan Balekambang dan Kelurahan Srengseng Sawah berada di kategori tinggi. Hal tersebut dikarenakan ancaman bencana banjir yang tinggi, walaupun kapasitas masyarakat dan daerah di segmen hilir berada pada kategori sedang. 
5) Analisis alternatif pengurangan risiko bencana banjir

Berdasarkan kajian terhadap perspektif tenaga ahli menggunakan metode AHP didapat alternatif peningkatan efektivitas pencegahan dan mitigasi bencana (alternatif 1) terpilih karena alternatif 1 mengutamakan pengelolaan lingkungan hidup yang dapat menurunkan frekuensi banjir dan luasan banjir, sehingga dampak yang ditimbulkan baik ekonomi maupun sosial berkurang. Salah satu kegiatan peningkatan efektivitas pencegahan dan mitigasi bencana adalah penerapan resapan air (biopori/sumur respan) untuk peningkatan efektivitas pencegahan dan mitigasi bencana banjir. Biopori/sumur resapan adalah salah satu metode resapan air yang ditujukan untuk mengatasi banjir dengan cara meningkatkan daya resap air pada tanah. Masyarakat dapat menerapkannya di lingkungan rumah, dan tanpa biaya yang banyak. Selain penerapan resapan air, kegiatan yang mengutamakan lingkungan hidup adalah restorasi sungai. Restorasi sungai adalah mengembalikan fungsi alami/renaturalisasi sungai, yang telah terdegradasi oleh intervensi manusia. Retorasi sungai merupakan perubahan paradigma dalam ilmu rekayasa sungai yaitu perubahan dari pola penyelesaian berdasarkan aspek teknik sipil hidro secara parsial menjadi penyelesaian terintegrasi asoek hidraulik, fisik, ekologi dan sosial. Perlindungan daerah tangkapan air juga merupakan salah satu kegiatan dalam alternatif peningkatan efektivitas pencegahan dan mitigasi bencana. Perlindungan daerah tangkapan air diharapkan dapat direalisasikan oleh pemerintah kota maupun provinsi yang berada di DAS Ciliwung dengan membuat kebijakan dan menerapkannya sampai kepada masyarakat. Secara hirarki tingkat prioritas kategori dan alternatif terbaik dapat dilihat pada Gambar 20.

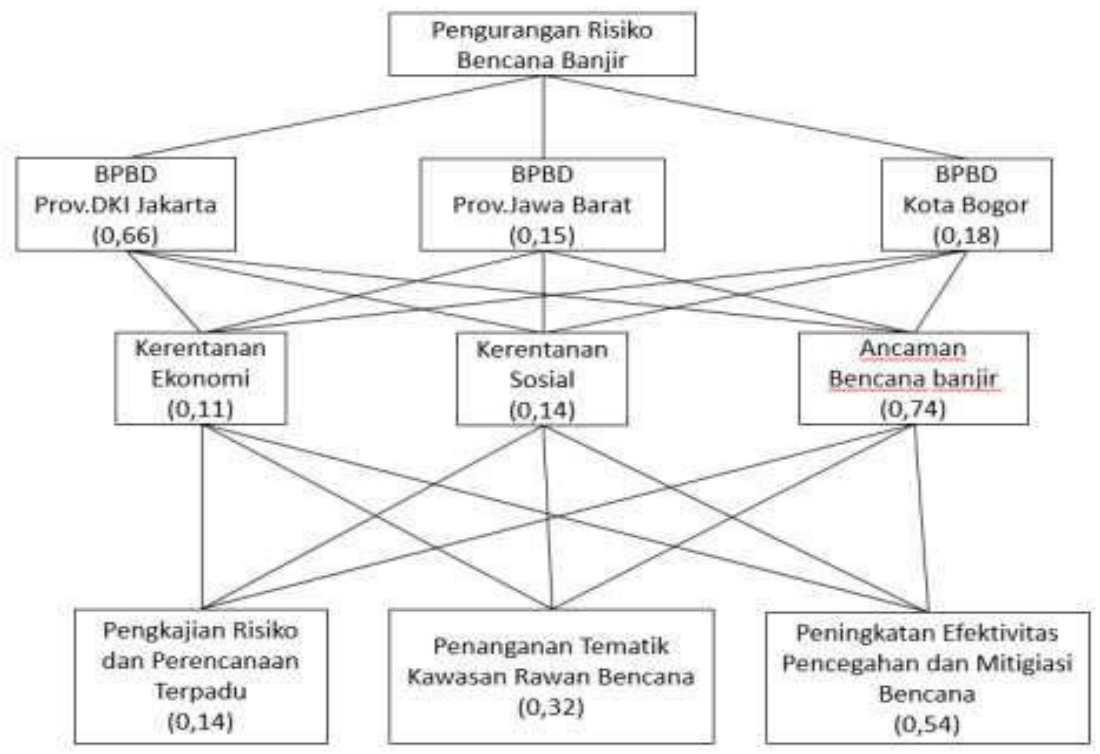


Gambar 20. Struktur Hirarki AHP dengan Bobot

\section{KESIMPULAN}

1. Tingkat risiko bencana banjir di DAS Ciliwung dipengaruhi oleh variabel ancaman bencana banjir, kerentanan (sosial dan ekonomi), kapasitas daerah dan masyarakat. Dalam hal ini kapasitas masyarakat dan daerah yang masih dalam kategori sedang tidak dapat mengurangi tingkat risiko bencana banjir yang tinggi di DAS Ciliwung.

2. Tingkat risiko bencana banjir kategori tinggi yakni tingkat ancaman dan kerentanan yang tinggi tetapi tingkat kapasitas daerah dan masyarakat rendah atau sedang.

3. Penilaian para ahli tentang alternatif pengurangan risiko bencana banjir yang tepat adalah peningkatan efektivitas pencegahan dan mitigasi bencana dengan kegiatan perlindungan daerah tangkapan air, restorasi sungai, revitalisasi waduk dan tanggul, pemantauan berkala hulu sungai, dan penerapan resapan air. 


\section{DAFTAR PUSTAKA}

------------. Peraturan Kepala BNPB nomor 02 tahun 2012 Tentang Pedoman Umum Pengkajian Risiko Bencana.

BPBD Provinsi DKI Jakarta. 2013. Rencana Penanggulangan Bencana Provinsi DKI Jakarta Tahun 2013-2017. Jakarta: BPBD Provinsi DKI Jakarta.

BPDAS Citarum-Ciliwung. 2003. Rencana Pengelolaan DAS Terpadu DAS Ciliwung. Jakarta: BPDAS Citarum-CIliwung.

2011. Penyusunan Rencana Detil Penanganan Banjir di Wilayah Jabodetabekpunjur. Bogor: Departemen Kehutanan.

BPS Kota Bogor. 2017. Kecamatan Kota Bogor tengah Dalam Angka 2017. Bogor: BPS Kota Bogor.

2017. Kecamatan Tanah Sareal Dalam Angka 2017. Bogor: BPS Kota Bogor.

BPS Provinsi DKI Jakarta. 2016. Jakarta Dalam Angka. Jakarta: BPS Provinsi DKI Jakarta.

-----------. 2017. Jakarta Selatam Dalam Angka 2017. Jakarta: BPS Provinsi DKI Jakarta. 2017. Jakarta Timur Dalam Angka 2017. Jakarta: BPS Provinsi DKI Jakarta.

LIPI-UNESCO/ISDR. 2006. Kajian Kesiapsiagaan Masyarakat dalm Mengantisipasi Bencana Gempa Bumi \& Tsunami di Indonesia. Jakarta: LIPI 